\title{
POR QUE FILMAR A NOSSA GUERRA? A SEGUNDA GUERRA MUNDIAL NO CINEMA BRASILEIRO: PANORAMA HISTÓRICO DE 1940 A 2015
}

\author{
WHY FILMING OUR WAR? WORLD WAR II IN THE \\ BRAZILIAN CINEMA: HISTORICAL OVERVIEW, 1940- \\ 2015
}

Cássio dos Santos Tomaim*

\begin{abstract}
Resumo: Objetiva-se apresentar um panorama histórico do Brasil na Segunda Guerra Mundial retratado pelo cinema brasileiro, apontar o lugar que esta memória ocupa em uma filmografia que se estende de 1940 a 2015. Em termos metodológicos, recorreu-se à pesquisa bibliográfica sobre o tema e à pesquisa documental com consultas ao banco de dados da Cinemateca Brasileira, Dicionários de Filmes Brasileiros e sites na internet. O mapeamento resultou em um total de 274 filmes, entre ficções e não ficções de curta, média e longametragem, no período estudado. Constatou-se que em mais de meio século o interesse do cinema brasileiro pela representação da FEB e do Brasil na Segunda Guerra Mundial foi ínfimo. Com exceção do período em que o Brasil esteve em guerra (1940-1945), foram esporádicas as produções ao longo das décadas no pós-guerra. Somente nos anos de 1960/70, em plena ditadura civil-militar, o interesse pela temática ressurge no cinema brasileiro, fato explicado pela aproximação da memória da FEB ao regime dos militares. Os filmes produzidos nos anos de 2000 integram tardiamente no Brasil uma política de memória sobre o passado da Segunda Guerra Mundial, por outro lado, têm mostrado preocupação por retratar episódios da guerra pouco explorados..
\end{abstract}

Palavras-chave: Força Expedicionária Brasileira (FEB); Segunda Guerra Mundial; Cinema Brasileiro.

* Universidade Federal de Santa Maria, Santa Maria, Rio Grande do Sul, Brasil. Prof. Programas de Pós-Graduação em História e em Comunicação da UFSM .E-mail: tomaim78@gmail.com 


\begin{abstract}
This paper aims to present a historical overview of Brazil in the World War II portrayed by Brazilian cinema, pointing the place on which this memory occupies in the filmography from 1940 to 2015. In methodological terms, we resorted the literature on the subject and the documentary research with queries to the database of the Brazilian Cinematheque, Film Dictionaries and Brazilian websites. The mapping resulted in a total of 274 films, including fiction and non-fiction short, medium and feature film, at the study period. It was verified that in more than half a century the interest of the Brazilian cinema for representing The FEB and Brazil on the World War II was pitiful. Excepting the period in which Brazil was at war (1940-1945), occured sporadic productions over the decades after the war. Only in the 60's and 70's, during the civilmilitary dictatorship, the interest about the theme resurfaces in the Brazilian cinema, fact explained by the approximation of the memory of The FEB to the regime of the military. The films produced on the years 2000 integrate delayed in Brazil a memory policy about past of the World War II, on the other hand, they have shown concern in portraying underexplored episodes of the war..
\end{abstract}

Keywords: Brazilian Expeditionary Force (FEB); Second World War; Brazilian film.

\title{
Introdução
}

Porque filmar a nossa guerra? Apesar da participação do Brasil na Segunda Guerra Mundial ser uma reserva simbólica das Forças Armadas, o mesmo sentimento não é compartilhado pelo Estado e pela sociedade civil, existe um profundo desconhecimento e desinteresse por parte dos brasileiros a respeito deste episódio. Desinteresse que não é de hoje, desde o pós-guerra a memória dos ex-combatentes vem sofrendo com o esquecimento a qual foi submetida ou com as apropriações feitas ao longo do tempo por certos projetos políticos de memória, como durante a ditadura civil-militar de 1964 a 1985 no Brasil, em que o passado da FEB (Força Expedicionária Brasileira) foi identificado com o projeto político do regime em vigor na época. Processo este que só veio a prejudicar uma memória que na década de 1960 ainda estava em construção.

Para muitos intelectuais, jornalistas, artistas e grupos de esquerda que vivenciaram este período no país, por terem sido censurados, perseguidos, exilados, torturados ou por terem algum familiar/amigo morto ou desaparecido, as expressões "FEB = Golpe" e "FEB = Repressão" não são difíceis de serem validadas no campo do imaginário. Apesar de muitos ex-combatentes não terem tido participação no golpe, ou sequer envolvimento com o regime e com as ações de repressão; mesmo que tantos outros febianos tenham sido perseguidos e expulsos das Forças Armadas, em decorrência de seus "pensamentos de esquerda", como parte de uma operação de higienização dos quartéis, a memória 
da FEB pagou um alto preço por ter entre os generais que arquitetaram o golpe os principais nomes do seu Estado Maior. Acrescenta-se a isto o fato de que durante os governos militares que se sucederam alguns febianos assumiram a linha de frente da ditadura, seja como Chefe de Estado (o primeiro foi o general Humberto de Alencar Castello Branco) ou liderando e organizando órgãos de repressão que culminaram em torturas, mortes e desaparecimentos de muitos daqueles que o regime condenou como "inimigos" do Brasil. A apropriação que o regime fez da memória dos ex-combatentes durante os mais de 20 anos, em nome da glorificação de um passado heróico, pode ser interpretada como uma das causas que levou a memória da FEB a ser combatida nos anos de 1990 por alguns intelectuais, jornalistas e cineastas que se aproveitaram do momento de "abertura política" para contra-atacar, o que para muitos soou como revanchismo. ${ }^{1}$

Somente a partir dos anos de 2000, nota-se um maior interesse de historiadores, sociólogos, antropólogos e inclusive de cineastas sobre o passado da FEB e dos ex-combatentes brasileiros. Os últimos 15 anos têm sido o período mais produtivo para a memória do Brasil na Segunda Guerra Mundial, nunca se escreveu e publicou tanto sobre este episódio da história brasileira. E o cinema tem acompanhado esta efervescência. É o que procurarei demonstrar aqui nesta proposta de traçar um panorama histórico de 1940 a 2015 dos filmes brasileiros que retrataram o tema da participação do Brasil na Segunda Guerra Mundial.

A pergunta "Porque filmar a nossa guerra?" nasceu do interesse por uma visão panorâmica do cinema brasileiro a partir do pós-guerra, principalmente movido pela constatação de que o desconhecimento, ou mesmo um total desinteresse pela atuação da FEB no conflito do Mediterrâneo, não era apenas nosso, dos brasileiros, mas também de outros países que também estiveram envolvidos na guerra.

Ao assistir a série documental Battlefield - As Maiores Batalhas da Segunda Guerra, exibida em 1996 na Inglaterra e nos EUA, e lançada no Brasil em 2008 pela Editora Abril, fui surpreendido ao saber que no episódio "Batalha na Itália" apenas os combates travados na Sicília nos anos de 1943 são retratados. A respeito das batalhas ocorridas nos apeninos italianos, em que os brasileiros estiveram envolvidos, há um total silenciamento em termos fílmicos. A série de 18 episódios foi produzida pela Universal Pictures, com consultoria do Professor John Erickson do Centre for Defense Studies da University of Edinburgh. Por mais que o conflito na Itália tenha durado até o fim da guerra em 1945, o documentário "explica" ao espectador indignado (principalmente, os historiadores brasileiros) que quando a batalha da Itália começou a ganhar dimensão para os destinos da Segunda Guerra, outra batalha, a da Normandia (França), em junho de 1944, chamou mais a atenção, tirando todo o foco do conflito no Mediterrâneo. É como se dissessem: "Foi preciso desligar as câmeras e partir. Não há registros". Mas como sabemos estas imagens dos pracinhas 
em combate existem, inclusive foram utilizadas em produções brasileiras dos anos de 1990 e 2000.

Mesmo que as imagens não existissem, o total desconhecimento (ou desinteresse) dos diretores da série de que brasileiros estiveram combatendo na "Batalha na Itália" é preocupante, várias forças expedicionárias que atuaram no Teatro de Operações no Mediterrâneo tiveram destaque no episódio da série mencionado, como as Divisões do Norte da África francesa, da Nova Zelândia e da Índia, do Canadá e da Polônia. A Divisão brasileira, a única sul-americana a compor as tropas Aliadas, não mereceu sequer uma breve menção. Monte Castelo, Montese e os brasileiros não existem para a memória da Segunda Guerra Mundial se levarmos em consideração esta produção norte-americana. Para corrigir esta ausência o encarte que acompanha o DVD, lançado no Brasil pela Editora Abril, traz em detalhes a "Campanha da Itália" da FEB. Em termos fílmicos prevalece o apagamento.

Se os brasileiros não reconhecerem como legítima a participação do Brasil na Segunda Guerra Mundial, que esta memória merece um tratamento mais crítico e sério, tanto de estudiosos quanto de cineastas, corremos o risco de repetir estereótipos e estigmas que condenam os ex-combatentes a figuras patéticas de nossa história, assim como ao próprio esquecimento. Contar esta história por meio do cinema e do audiovisual é uma forma de colaborar na construção de uma memória do Brasil na guerra, haja vista que cinematografias de outras nações envolvidas no conflito trataram logo de contar seus dramas, pavores, vitórias e derrotas, deram (e continuam dando) suas versões a respeito deste episódio que marcou o século XX.

Que histórias o nosso cinema contou a respeito dos pracinhas brasileiros no pós-guerra? Para responder a esta questão recorro a uma história panorâmica do cinema brasileiro, mesmo consciente de que ao buscar abarcar um todo se perde em especificidades, em detalhes, em aprofundamentos. A partir de uma preocupação mais generalizante com a memória da FEB no cinema brasileiro, este trabalho objetiva apontar o lugar que esta memória ocupa em uma filmografia que se estende de 1940 a $2015 .^{2}$

Em termos metodológicos, recorreu-se à pesquisa bibliográfica sobre o tema "Brasil na Segunda Guerra" e à pesquisa documental com consultas ao banco de dados da Cinemateca Brasileira, Dicionários de Filmes Brasileiros ${ }^{3} \mathrm{e}$ sites na internet. As consultas não priorizaram um tipo de cinema, ficção ou não ficção, tão pouco se concentrou no longa-metragem como formato. Buscou-se contemplar todo tipo de produção que pudesse nos dar uma pista de como o passado do brasileiro na Segunda Guerra foi representado nos filmes nacionais.

Percorrendo o banco de dados da "Filmografia Brasileira", disponível no sítio eletrônico da Cinemateca Brasileira (www.cinemateca.com.br), podemos deparar com produções audiovisuais de 1897 a 2007, dentre elas longasmetragens, curtas-metragens, cinejornais e filmes domésticos. Entretanto, é 
importante destacar que a presença dos registros aqui apontados nem sempre pressupõe a existência dos filmes no acervo da Cinemateca Brasileira, como o próprio sítio faz o alerta. Sobre a temática da Segunda Guerra Mundial e a FEB foi possível encontrar neste banco de dados um universo de aproximadamente 270 filmes, pesquisando on-line com a seguinte forma de busca: "FEB or Guerra Mundial, 2 and Data". Depois de uma leitura detalhada de todas as fichas chegou-se a um número de 247 filmes que fazem citações diretas à FEB e a episódios do Brasil na Segunda Guerra. Recorreu-se aos Dicionários de Filmes Brasileiros com o objetivo de complementar a pesquisa, tendo em vista que o autor destas obras também tem a "Filmografia Brasileira" da Cinemateca como uma de suas fontes, porém, suas pesquisas contemplam um número maior de fontes (catálogos de festivais, relatórios da ANCINE, etc) e um período mais extenso, 2009, no caso de filmes de longa-metragem, e 2011, no caso de filmes de curta e média-metragem. Também foi feita uma consulta a internet visando o mapeamento de produções mais recentes que poderiam não ter sido contempladas por ambas as fontes.

O mapeamento resultou em um total de 260 filmes, entre ficções e não ficções de curta, média e longa-metragem, no período de 1940 a 2015. Vale destacar que algumas produções podem ter ficado de fora, por estas não terem sido catalogadas em uma das fontes consultadas, entretanto, compreendo que os dados apresentados por estas buscas são capazes de nos fornecer um desenho confiável para o panorama que desejo traçar do cinema brasileiro.

Por se tratar de um universo de mais de duzentas produções, os relatos sobre os filmes são baseados nas sinopses disponíveis nas fontes consultadas. Não se pretende neste estudo apresentar uma análise estética dos filmes, mas fornecer uma interpretação sobre o percurso histórico do tema "Brasil na Segunda Guerra" no cinema brasileiro.

O Brasil em guerra (1940-1945)

Em meados de 1940, a aliança Brasil-EUA não era sequer um exemplo de boa vontade unilateral, longe de uma solidariedade hemisférica como os norte-americanos idealizavam na época. Desde o início do conflito na Europa, o Brasil procurou manter-se, enquanto possível, em uma posição "neutra" que favorecesse negociações tanto com os EUA quanto com a Alemanha, apesar do traço autoritário do Estado Novo. A principal aproximação com o bloco dos Aliados se deu com o financiamento da Companhia Siderúrgica Nacional de Volta Redonda e o fornecimento de armamentos que modernizariam as Forças Armadas. Em troca, o Brasil colocou a sua indústria a serviço do esforço de guerra norteamericano, fornecendo matéria-prima para o interesse bélico dos EUA, além de permitir que construíssem bases militares no Nordeste. Segundo Francisco Luiz Corsi, este alinhamento começou a melhor delinear-se com a 
entrada dos EUA na guerra em $1942^{4}$. É quando o Brasil pela primeira vez tem a sua soberania ameaçada pelas ações dos submarinos alemães na costa brasileira, afundando navios, ferindo e matando muitas pessoas. Somente em 22 de agosto de 1942 o Brasil decretou guerra aos países do Eixo.

Muitas das lideranças políticas e militares do Estado Novo desejavam uma participação mais direta do Brasil no conflito mundial, a concessão das bases aéreas e navais aos Aliados e o fornecimento de matérias-primas estratégicas para o esforço de guerra não eram suficientes. Era preciso enviar tropas ao Teatro de Operações. Em novembro de 1943 foi criada a FEB (Força Expedicionária Brasileira), um projeto político-militar que, segundo Gerson Moura, deveria colaborar para a disputa do Brasil pela hegemonia na América do Sul. ${ }^{5}$ No entanto, o primeiro embarque das tropas brasileiras para a Itália ocorreu em 2 de julho de 1944.

No período em que o Brasil esteve em guerra concentra-se o maior número de filmes produzidos sobre o tema "Brasil na Segunda Guerra", de 1942 a 1945 somam-se 169 produções nacionais, 65\% de todos os filmes mapeados por este estudo. Os números se tornam ainda mais expressivos se nos atentarmos para o curto período em que se concentra esta produção, quatro anos, tendo em vista o longo período de 75 anos contemplados no mapeamento. Antes da declaração de guerra, há registros de apenas 03 produções. No Cine Jornal Brasileiro do DIP v.1, n.086, datado de 1940 aparece o assunto "Para defender a neutralidade da América - Rio: O presidente Getulio Vargas inaugura os trabalhos da Conferência Interamericana" em meio a outros temas noticiados na época, como o carnaval carioca e o aparelhamento da agricultura nacional. Já em 1941 o Cine Jornal Brasileiro v. 2, n.075, noticiava o torpedeamento do navio norteamericano I. C. White ao largo da costa brasileira. Uma produção independente de Genil Vasconcelos retratou o mesmo episódio naquele ano.

É interessante notar como a produção de cinejornais dá um salto nos anos em que se segue após a declaração de guerra do Brasil. Em 1942 são 39 filmes, sendo que se mantém certo equilíbrio até 1945 quando se registra 56 produções. 
Gráfico 1: Filmes FEB/Segunda Guerra x Ano de Produção

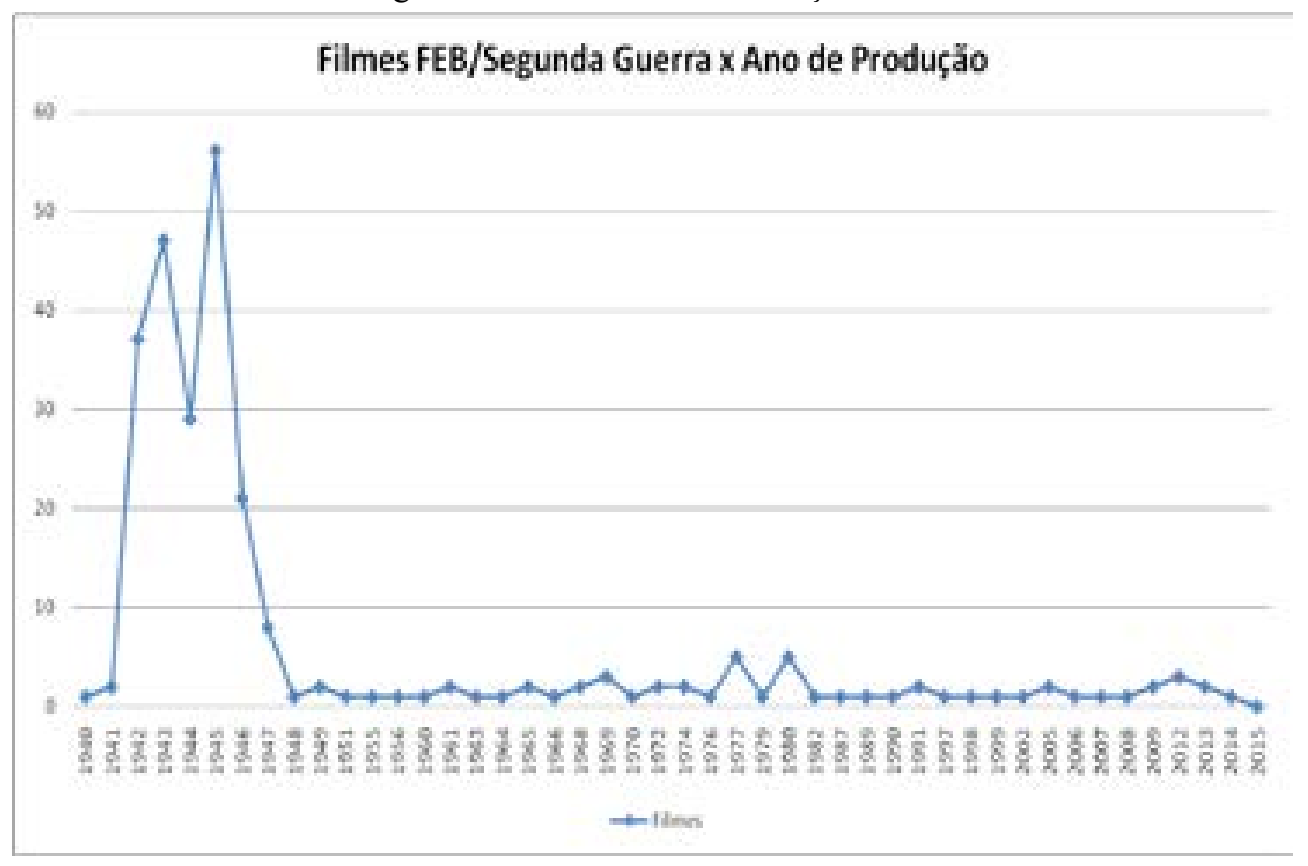

Fontes: Consulta Filmografia Brasileira/Cinemateca Brasileira; Dicionários de Filmes.

Os picos de produção na primeira metade da década de 1940 compreendem uma cinematografia nacional que colaborou com o esforço de guerra brasileiro, a maioria é cinejornais ou filmes de atualidades (curtasmetragens de não ficção) de propaganda política do Estado Novo que abasteciam o front interno. O Departamento de Imprensa e Propaganda (DIP) produziu 89 filmes ${ }^{6}$ em cinco anos, seguido por outros órgãos como o Serviço de Informação Agrícola (SIA), do Ministério da Agricultura, uma vez que a produção de filmes de propaganda e educativos não era uma exclusividade do DIP dentro do projeto político do Estado Novo. ${ }^{7}$

Mas também houve empresas do setor cinematográfico brasileiro que se interessaram pelo tema, a Atlântida Empresa Cinematográfica do Brasil e a Pan Filmes do Brasil foram responsáveis por produzirem juntas 44 cinejornais entre os anos de 1942 e 1945, o equivalente a $26 \%$ dos filmes realizados durante o período em que o país esteve em guerra. ${ }^{8}$ A Atlântida produziu o Notícias da Semana e a Pan Filmes outros três títulos de cinejornais: Imprensa Animada, Imagens D'Amanhã e Brasil Atualidades. Destaque também para a Carriço Filmes, produtora de Juiz de Fora (MG), responsável pela produção de 07 filmes do Cinejornal Carriço que dentre os assuntos noticiados na época um ou mais tratava da participação do Brasil na guerra. Outras empresas do setor cinematográfico também deram as suas contribuições para o esforço de guerra: Filmes Artísticos Nacionais, Cooperativa Cinematográfica Brasileira, Meridional Filmes, Aviação Filme, Sonofilmes, Botelho Film, Rex Filme, 
Cinelândia Filmes, Cinédia, Cruzeiro Filmes, Vitória Filmes, Companhia Sul Americana de Filmes, Brasil Vita Filmes e a Gianelli Filmes. Nomes como de Pedro Neve, J. Tinoco de Freitas, João Batista Groff, Hikoma Udihara e Jurandyr Passos Noronha aparecem como diretores de produções independentes. Esta diversidade de produtoras e realizadores demonstra o quanto o tema "Brasil na Segunda Guerra" movimentou a produção de filmes no país no período de 1942 a 1945 para além da produção estatal. Porém, o traço da propaganda política da época atravessa estas produções, não é difícil identificar em alguns títulos e sinopses a glorificação do soldado-guerreiro, principalmente no fim do conflito mundial, como em $A$ Volta dos Heróis de Monte Carlo (Botelho Film, 1945), A Volta dos Heróis (J. Tinoco de Freitas, 1945), Contribuição da FAB para a Vitória (Aviação Filme, 1945) entre outros.

Dentre os diversos assuntos correlatos que são tratados nestes cinejornais, um em especial nos chamou a atenção por extrapolar o universo estritamente masculino que é a guerra: o da participação da mulher brasileira neste conflito bélico, seja como enfermeira ou atuando na Legião Brasileira de Assistência. Assuntos como A Mulher e a Guerra - Rio: Mais voluntárias socorristas para a Cruz Vermelha (1942), A contribuição obscura e valiosa da mulher brasileira (1943) são encontrados em meio a outros tantos assuntos noticiados pelos filmes da época. Destaque para duas produções de cinejornais de assuntos únicos que são dedicados a figura feminina na guerra: $A$ Mulher Brasileira e a Guerra (1942) da Filmes Artísticos Nacionais, e Mobilização Feminina (1943) da Aviação Filme. Ambos os filmes retratam a participação da mulher brasileira no esforço de guerra. No entanto, estes dois curtas-metragens e outras citações dentre tantos outros assuntos nos cinejornais da década de 1940 são as únicas representações. No pós-guerra há um apagamento da figura feminina na história da FEB e do Brasil na Segunda Guerra, vendo pela perspectiva do cinema nacional.

A consulta ao banco de dados da Cinemateca Brasileira também nos apresenta outras sete produções estrangeiras que chamam a atenção. São filmes do Reino Unido (UK) e EUA (US) que percorrem os anos de 1942 a 1945, período em que o Brasil se viu envolvido diretamente com os países aliados e a guerra que acontecia na longínqua Europa. A produtora S. G. Balcon Ealing Studios (UK) realizou em 1942 um longa-metragem de ficção intitulado Went The Day Well? (traduzido no Brasil para Quarenta e Oito Horas), cujo enredo retrata o cotidiano de uma pequena cidade no interior da Inglaterra atacada por pára-quedistas alemães disfarçados de soldados britânicos em operação. Mas logo os habitantes percebem que foram enganados e começam a luta contra os inimigos com a ajuda de um caçador. Quem assina a direção deste filme é o cineasta brasileiro Alberto Cavalcanti que trabalhou como produtor, diretor e cenógrafo em mais de 120 filmes, em vários países europeus: França, Inglaterra, Itália, Alemanha, Áustria, Israel. Na Inglaterra, Cavalcanti deu uma enorme 
contribuição nos anos de 1930 ao documentário britânico de cunho social ao aceitar o convite de John Grierson para integrar a equipe do General Post Office Film Unit na produção de filmes institucionais e educacionais. Mas foi durante a Segunda Guerra Mundial que o diretor brasileiro começou a trabalhar para os estúdios Ealing, de Michael Balcon, um dos pilares da indústria inglesa. Quarenta e oito horas é o primeiro e único filme na Grã-Bretanha, produzido durante a guerra, a aceitar a hipótese de uma invasão alemã.

A British Pathé (UK) realizou dois cinejornais, Brazil comes in (1942) e News and views from Italy (1944). O primeiro registra as comemorações da população nas ruas do Rio de Janeiro pela declaração de guerra do Brasil aos países do Eixo; já o segundo, procura retratar as cenas de guerra na Itália e o desembarque das tropas brasileiras em Nápoles. Em 1943, temos o registro do documentário de curta-metragem São Paulo que materializou nas telas a aliança Brasil-EUA. Trata-se de uma co-produção entre a Coordenadoria de Assuntos Inter-Americanos/Missão Cinematográfica John Ford e o DIP do Estado Novo. O filme de 15 minutos, financiado pelo governo brasileiro e por Nelson Rockfeller, é uma seleção de imagens e sons sobre os mais diversos aspectos do esforço de guerra brasileiro e das regiões características do Brasil.

Ainda em 1943, encontramos o registro do cinejornal Pathe Gazette N.43/7, da Pathe Gazette (UK), que faz referência à preparação do Brasil para a defesa do porto do Rio de Janeiro, ao colocar na entrada da Baía da Guanabara uma rede metálica anti-submarina. Nos anos seguintes, encontramos mais duas produções norte-americanas: Brazilians ready for global war (1944) e Brazilian expeditionary forces in Italy (1945) - título traduzido como Primeiras forças expedicionárias brasileiras. A primeira película foi produzida pela Universal Pictures e documenta, em São Paulo, a cerimônia de saudação das tropas brasileiras que iriam lutar com os Aliados; a outra é uma realização da Office of Center American Affairs e também trata da formação do corpo de expedicionários brasileiros que iriam para o front na Itália.

A existência destes registros demonstra o interesse dos países Aliados em representar no cinema o envio das tropas brasileiras que iriam lutar no teatro de operações na Itália, mesmo que já nos últimos anos da guerra. O que torna ainda mais inexplicável o silenciamento a respeito da presença de brasileiros no conflito décadas mais tarde na série Battlefield - As Maiores Batalhas da Segunda Guerra (1996), como mencionado anteriormente, uma produção da própria Universal Pictures, responsável por um dos filmes produzidos nos anos de 1940.

Brasil, a guerra acabou

Nos primeiros anos do pós-guerra o cinema brasileiro começou a se desinteressar gradativamente pelo tema "Brasil na Segunda Guerra", é 
como se acompanhasse ou refletisse o processo de esquecimento a que foram submetidos os ex-combatentes brasileiros. Em 1946 foram 21 películas, já em 1947 apenas oito filmes foram realizados sobre o tema. Na década de 1950 três filmes foram produzidos.

Por meio do Aviso n. 217.185, de 6 de julho de 1945, do Ministério da Guerra, a FEB foi dissolvida ainda na Itália. $\mathrm{O} 1^{\circ}$ Escalão de expedicionários somente desembarcou no Rio de Janeiro em 18 de julho daquele ano. Chegando ao Brasil a ordem era que os ex-combatentes deveriam retornar "às atividades do tempo de paz." Segundo Francisco Ferraz, as motivações dessa dissolução e, posteriormente, desmobilização foram fundamentalmente de cunho político e afetaram a reintegração social dos expedicionários que foram proibidos de narrar suas experiências da guerra. O objetivo era amenizar o impacto da chegada da FEB nas eleições presidenciais de 1945, uma vez que o general Eurico Gaspar Dutra, então Ministro da Guerra, seria candidato e sabia que não teria o apoio dos oficiais febianos. ${ }^{9}$

Se o Estado e a sociedade civil não demonstraram interesse pela memória da FEB, os ex-combatentes começaram a se mobilizar em torno de associações. Aparentemente, o cinema estava entre as ações de combate ao esquecimento da Associação dos Ex-Combatentes da FEB, pelo menos no início do pós-guerra em que se tinha uma postura mais ativa da entidade. ${ }^{10}$ Em 17 de dezembro de 1949 era noticiado no jornal O Estado de São Paulo: "Excepcionalmente! Amanhã no Cine Bandeirantes às 10:30 da manhã: JORNADA HERÓICA (...) Espetáculo Beneficente da Associação dos Ex-Combatentes da FEB". ${ }^{11}$ O filme Jornada Heróica, documentário de longa-metragem da FAN Filmes (Filmes Artísticos Nacionais), com direção de Alexandre Wulfes e narração de Alberto Madeira, levou três anos para ser concluído e teve a colaboração da Associação dos Ex-Combatentes do Brasil (AECB), por isto o espetáculo beneficente anunciado pela imprensa. Ao longo das décadas não há outro registro similar a este, não se sabe se outras produções contaram com o apoio direto da $\mathrm{AECB}$ ou se ela própria produziu filmes dedicados à construção da memória da FEB.

Uma década depois do término da Segunda Guerra parece que no Brasil não há nada a ser lembrado a respeito deste acontecimento que marcou a história do século XX, pelo menos não para o cinema nacional. Nos anos de 1950 o silenciamento é uma constante, apenas três filmes foram produzidos sobre o tema. O primeiro é um registro em 1951 de um desfile de ex-combatentes em Minas Gerais feito pela câmera da Carriço Filme para o seu Cinejornal Carriço. SN-092. Em 1955 é lançado o longa ficcional A Paz Volta a Reinar, da Produções Cinematográficas Liberdade, de São Paulo (SP), com direção de Yoshisuke Sato. O filme é um drama que narra a história de um imigrante japonês no Brasil de 1947. No interior do Estado de São Paulo, adaptado à cultura local e noivo da filha de um fazendeiro, o personagem acaba se envolvendo com a 
crescente tensão de seus compatriotas que se recusam a acreditar na derrota do Japão na Segunda Guerra. O mesmo tema vai ser retratado anos mais tarde em outro longa-metragem ficcional, Corações Sujos (2012), de Vicente Amorim, baseado no livro homônimo de Fernando Morais. Em 1956 o tema da FEB aparece pela última vez na década em um curta-metragem de não-ficção. $O$ filme Pistoia registra a homenagem feita no Cemitério Brasiliano di Pistoia, na Itália, aos soldados da FEB mortos durante a Segunda Guerra Mundial, a partir da ótica de uma família de campesinos que relembra o episódio. O filme é uma produção da Cinematográfica Brasil Filme, com argumento, roteiro e direção de César Mêmolo Júnior e locução de Wandisa Guida.

Nas décadas de 1960 e 1970 começa a ser ensaiado um retorno acanhado desta produção, mas que no final contabiliza 25 filmes produzidos. $\mathrm{O}$ regime civil-militar instaurado em 1964 aos poucos vai demonstrando interesse na memória da FEB, apropria-se dos mitos da "Campanha da Itália" a ponto de associar a luta dos pracinhas na Europa ao combate contra o comunismo no Brasil dos anos de 1960/70, inimigo número um da soberania brasileira no entendimento dos militares no poder. E no cinema brasileiro deste período vemos os reflexos deste projeto político para a memória da FEB. Por outro lado, é interessante notar que de 1964 a 1985 as produções não se resumem apenas a filmes oficiais do regime, de um universo de 27 filmes mapeados no período treze (13) são produções de empresas do setor cinematográfico brasileiro, como a Jean Manzon Filmes, Produções Cinematográficas Herbert Richers, Cinedistri, União Cinematográfica Brasileira (UCB), Cinesul, Wilson Silva Produções Cinematográficas, Sylvio Back Produções Cinematográficas, Produções Carlos Niemeyer Filmes, Magnus Filmes e Teleobjetiva Filmes; além de outras produções assinadas por realizadores como Antonio Manuel e Gilson Giehl.

Vale destacar as produções de dois documentários de longa-metragem na década de 1970, no primeiro a participação da FEB na guerra tangencia a narrativa, já no segundo a FEB é protagonista. 70 Anos de Brasil (da Belle Époque aos Nossos Dias) é uma realização da Cinesul, com direção de Jurandyr Passos Noronha, cineasta que assina outras produções no período, inclusive alguns filmes do Instituto Nacional de Cinema Educativo (INCE) e do Instituto Nacional de Cinema (INC). ${ }^{12}$ Este documentário de 1972 nasceu da montagem de antigos filmes atualidades, após uma pesquisa do diretor em mais de 800 rolos de películas espalhados pelo país, e homenageia os pioneiros do nosso cinema como Afonso Segreto, Alberto Botelho e Paulino Botelho, João Stamato e Fernando Stamato, Luiz Thomaz Reis, Silvino Santos e Gilberto Rossi ao fazer uso de seus registros visuais dos principais eventos culturais, políticos e econômicos do Brasil do século XX. No emaranhado de imagens o filme passa pela Semana de Arte Moderna, Revolução Constitucionalista de 1932, acena aos primeiros bailes de carnaval, para depois depararmos com o desfile de 
despedida da FEB gravado com som direto, além da atuação dos combatentes brasileiros na Itália. É uma citação dentre tantas outras. Em 1974 é lançado o filme A Cobra está Fumando, uma produção da Wilson Silva Produções Cinematográficas, o primeiro longa-metragem de não-ficção sobre o tema de que temos registro. Sob a direção de Wilson Silva, o filme retrata a participação da FEB na Segunda Guerra Mundial, evidenciando as batalhas, os mortos e as homenagens aos soldados quando do regresso. Segundo a ficha indicativa do filme trata-se de uma película montada a partir de "material documental autêntico obtido por cinegrafistas americanos, alemães, ingleses, franceses, italianos e brasileiros". De acordo com a sinopse o filme também conta com reconstituições do tempo de guerra, evidenciando aspectos humanos quando recria as patrulhas, o contato do soldado brasileiro com os primeiros mortos e o torpedeamento de navios mercantes do Brasil por submarinos do Terceiro Reich. No elenco estão nomes como de Paulo Goulart e Augusto César Vannucci, e a narração é de Paulo César Peréio. O material reconstituído fazia parte de Eles não voltaram, longa-metragem ficcional dirigido por Wilson Silva em $1960 \mathrm{e}$ que teve a colaboração do Exército para retratar a "epopéia gloriosa de nossos pracinhas na Itália".

A Cobra está Fumando de Wilson Silva talvez seja o primeiro documentário que ao tratar o tema da FEB escapa à estética padrão dos noticiários cinematográficos que são responsáveis por mais de $80 \%$ de toda a produção sobre o "Brasil na Segunda Guerra", entre os mais de quarenta anos em que este tipo de filme teve presença garantida (e obrigatória por meio de leis de incentivo à produção e exibição) ${ }^{13}$ nas salas de exibição de cinema no país.

Em 1977, o curta-metragem de não-ficção Uma parada, escrito e dirigido por Antonio Manuel, é dedicado aos ex-combatentes da Segunda Guerra. O filme é premiado no Festival Brasileiro do Curta-Metragem no mesmo ano, no Rio de Janeiro. Mas durante o festival o documentário teve sua exibição proibida pela censura da época, conforme registros da Cinemateca. ${ }^{14}$

É interessante notar que durante os anos da ditadura, 11 filmes de atualidades foram produzidos pelos mais diversos órgãos estatais. Há registros de produções do Instituto Nacional de Cinema Educativo (INCE), da Assessoria Especial de Relações Públicas (AERP), do Instituto Nacional de Cinema (INC) - que veio a substituir o INCE em 1966 - e da Agência Nacional. Se compararmos com o período de esforço de guerra, 1942-1945, em que em um único ano produziu-se mais de 40 filmes, é notório que o tratamento dado à FEB pelo cinema brasileiro em tempos de ditadura não foi o mesmo, pelo menos em termos quantitativos. Por outro lado, é preciso ressaltar que a maioria dos filmes da primeira metade da década de 1940 integra um corpus específico da filmografia brasileira, são filmes de propaganda política, ou seja, filmes com um viés ideológico determinado pelos interesses políticos do Estado Novo, um regime autoritário que estava envolvido diretamente em um enorme conflito 
mundial e precisava dar visibilidade às ações de esforço de guerra, dentre elas o envio das tropas. Nos anos de 1964 a 1985 a guerra é outra. Os militares no poder se encarregam de militarizar a imagem da FEB apropriando-se de uma memória heróica que precisa ser cultivada no coração dos brasileiros, ao invés de negada como ocorreu na década anterior. O que esta amostra indica é que o regime não mediu esforços dos seus órgãos de propaganda e comunicação para difundir no país, por meio de cinejornais, a imagem de uma FEB vitoriosa.

Por mais que estes filmes oficiais representem um número pouco expressivo é importante notar que são eles os responsáveis por manter um constante recordar do passado da FEB e do Brasil na Segunda Guerra. Durante os mais de 20 anos da ditadura a FEB foi assunto, tendo sido produzido um filme em média por ano. Ainda é preciso um estudo mais aprofundado para sabermos quais foram as contribuições destes filmes para a memória da FEB e da participação do Brasil na Segunda Guerra Mundial. Em que medida o militarismo atravessa esta memória?

A partir de uma leitura global dos filmes mapeados neste estudo, o que se pode mencionar é que há marcas deste processo de militarização da imagem da FEB e dos ex-combatentes brasileiros. O cinejornal Atualidades Brasileiras n.439, da Produções Cinematográficas Herbert Richers, noticia já em 1964 homenagens aos soldados brasileiros, durante evento realizado no Monumento aos Mortos da II Guerra Mundial no Rio de Janeiro. Em 1965, um cinejornal é dedicado exclusivamente ao tema do monumento. O monumento: Monumento Nacional aos Mortos da Segunda Guerra Mundial, produção do INCE, com direção de Jurandyr Passos Noronha retrata a arquitetura, a escultura metálica, os painéis de cerâmica e os afrescos que compõem o monumento localizado no Aterro do Flamengo no Rio de Janeiro (RJ). No filme estes diversos aspectos do monumento são apresentados aos espectadores por meio de uma narrativa que faz uso de música eletrônica e concreta, a narração é por conta de Arnaldo Jabor. Os filmes estatais parecem perseguir o tema do monumento, em 1970 o cinejornal da AERP intitulado Dia do Soldado retoma o assunto ao apresentar "Planos diversos do Monumento a FEB no Rio e como frase final: 'A sua tranquilidade está em boas mãos"." ${ }^{15}$

Em 1969, o INC produz O Brasil na Guerra: A FEB Contra o NaziFacismo, com direção de Jorge Ileli. O curta não ficcional é montado com filmes de arquivo sobre a participação do Brasil na Segunda Guerra, procurando apresentar os principais fatos ocorridos na Europa que ocasionaram o conflito e, posteriormente, o envio das tropas brasileiras.

É no final da década de 1970 que se nota um maior empenho dos órgãos de propaganda e comunicação em aproximar a FEB da imagem do regime. Várias edições do cinejornal Brasil Hoje, produções da Agência Nacional de 1977, dão pistas da presença de ex-combatentes nos principais eventos militares da ditadura. No Brasil Hoje n.226 o presidente Ernesto Geisel 
comparece às comemorações do aniversário da Intentona Comunista e presta homenagens às vítimas deste episódio. ${ }^{16}$ No palanque, militares da ativa e da FEB dividem espaço. Em outra edição do cinejornal, n. 213, os pracinhas aparecem desfilando ao lado de marinheiros, PM, Escola Militar e banda militar durante as comemorações do Sete de Setembro daquele ano. Já as edições 196 e 199 do Brasil Hoje retratam a Comemoração do $32^{\circ}$ Aniversário do Dia da Vitória, realizado no Monumento aos Mortos da Segunda Guerra Mundial no Rio de Janeiro. No evento, Geisel está presente e os ex-combatentes seguem em desfile.

Em 1979, as comemorações do Dia da Vitória continuam sendo organizadas pelo regime, o então Presidente João Figueiredo comparece à cerimônia, assim como fez os seus antecessores. E lá estava a câmera da Agência Nacional para registrar o evento para o Brasil Hoje n. 268. Neste cinejornal mais uma vez os ex-combatentes desfilam ao lado da tropa do Exército. Mas foi em um filme do Centro de Comunicação Social do Exército de 1982 que deparamos com uma tentativa mais clara da associação da luta dos pracinhas e o combate ao comunismo pelo regime. Em Exército: Compromisso com a Democracia comemora-se o décimo oitavo aniversário da "Revolução de 31 de Março", em que a narrativa do filme procura assegurar ao espectador o compromisso do Exército Brasileiro com a democracia. Para demonstrar o repúdio do regime ao comunismo e ao nazismo, imagens de Hitler, da invasão da Hungria pela União Soviética em 1956, da construção do muro de Berlim em 1951, e do desembarque brasileiro na Itália durante a Segunda Guerra Mundial são mostradas. Próximo do fim da ditadura, a imagem da FEB é "convocada" pela primeira vez pelo cinema brasileiro para combater o comunismo que assolava o regime. Em clima de abertura política, era preciso confirmar os votos do Exército ao retorno de uma sociedade democrática, e nada soava melhor do que a luta travada por brasileiros na longínqua Itália. ${ }^{17}$

\section{E a ficção?}

Atentando para o filme de ficção brasileiro veremos que quando o assunto é a FEB e o Brasil na Segunda Guerra há uma incipiente produção nacional compreendendo o período de 1940 a 2015. São apenas 14 filmes registrados, sendo que destes 10 são produções de longa-metragem. Um dado preocupante se levarmos em consideração que o longa-metragem ficcional ainda é a principal vitrine do cinema brasileiro. $O$ fato é que o filme de curta e média-metragem, seja ele ficcional ou não ficcional, não tem espaço nas salas comerciais de cinema pelo país. Este tipo de cinema sempre ficou restrito aos públicos de festivais ou de espaços alternativos de cinema.

Por outro lado, é preciso fazer uma ressalva, não se trata de valorizar o longa de ficção como o principal ingrediente de uma filmografia nacional. 
Isto seria o mesmo que repetir o erro da historiografia clássica do cinema brasileiro que condenou o nosso cinema a uma história do filme ficcional de longa-metragem, desprezando uma produção enorme de filmes de curta e média-metragem de ambos os tipos de cinema (ficção ou documentário), como constatou Jean-Claude Bernardet. Longe disto, reconheço que o lugar da representação da FEB no cinema brasileiro é o campo documental, perspectiva que a partir de 2000 vem cada vez mais sendo fortalecida pelas produções sobre o tema que conquistaram visibilidade na mídia, levaram públicos aos cinemas e etc. Da mesma forma, considero o filme ficcional (seja ele longa, curta ou média-metragem) outro tipo de cinema capaz de dialogar com o espectador de formas diferentes do que o documentário, as histórias da FEB e dos brasileiros na guerra podem ter outros contornos que o documentário não é capaz de nos fornecer.

Dentre os nossos registros, o primeiro filme de enredo que tratou do tema data de 1948. Fogo na Canjica é uma comédia romântica da Cinédia que conta a história de João, pracinha da FEB, que ao ir para a guerra na Itália deixa no Brasil a sua noiva Maria. Mas em uma das patrulhas João não volta e é dado como morto. Incentivada pelos pais, Maria torna-se noiva de outro homem, Antônio, mesmo ainda gostando de João. Entretanto, durante uma comemoração de festa junina, o ex-combatente aparece surpreendendo a todos que acreditavam que tinha morrido. Na verdade, ele tinha sido ferido e preso, mas os americanos o haviam libertado e sua demora dera-se em razão do tempo que passou nos Estados Unidos recuperando-se dos ferimentos. Agora, Maria estava noiva de dois homens, o que muito incomodava o seu pai, o coronel Fulgêncio, que arranjara os compromissos. Mas Antônio percebe a felicidade de Maria ao ver João e vai embora para que ela viva o seu "verdadeiro amor. João e Maria se beijam diante do céu invadido por fogos de artifício". O roteiro, a montagem e a direção de Fogo na Canjica são assinados por Luiz de Barros. Próximo dos dez anos do fim da guerra é lançado em 1955 A Paz Volta a Reinar, única produção ficcional a ser realizada na década de 1950 sobre o tema da Segunda Guerra, e já mencionada anteriormente.

Nos anos de 1960 três filmes de ficção são produzidos: Eles não voltaram (1960), Por um céu de liberdade (1961) e Os carrascos estão entre nós (1968). O primeiro é uma produção carioca da Celestial Filmes, dirigido por Wilson Silva. Eles não voltaram teve a colaboração do Exército para retratar a "epopéia gloriosa de nossos pracinhas na Itália". No elenco do filme estão alguns nomes como Paulo Goulart, Augusto César, Dary Reis, Gilda Maria, Milton Vilar, Isa Rodrigues entre outros. O segundo, Por um céu de liberdade, é uma dramatização a respeito da atuação da Força Expedicionária Brasileira na tomada de Monte Castelo, uma co-produção da Empresa Paulista Cinematográfica e da Condor Filmes. O roteiro é de Daniel Rocha e Jairo Pinto de Araújo, com a direção de Luiz de Barros. Por final, Os carrascos estão 
entre nós trata-se de uma película que, na linha dos filmes policiais, procura retratar a investida de um norte-americano e um capitão do Exército brasileiro, vinte anos depois do fim da guerra, na caça ao nazista Martin Bormann, uma das mais importantes autoridades do Reich alemão que, juntamente com seus cúmplices, teriam embarcado em um submarino em direção à América do Sul, a fim de manterem acesos os ideais do nazismo, após a tomada de Berlim. Martin Bormann teria dado a ordem para que se afundasse o submarino na costa brasileira com toda a tripulação, na tentativa de não deixar rastros de seu paradeiro. Os carrascos estão entre nós é uma produção da Cinedistri, com a direção de Adolpho Chadler. Associado a Oswaldo Massaini e Cyll Farney nesta produção, aparece Anselmo Duarte, na época cineasta já consagrado ao conquistar a Palma de Ouro no Festival de Cannes com o filme O Pagador de Promessas (1962). ${ }^{18}$

Mais tarde em 1976, o único cineasta a arriscar enveredar pela temática do Brasil e a Segunda Guerra foi Sylvio Back, que com Aleluia, Gretchen desnuda a imigração alemã no sul do país e sua relação com o nazismo e o integralismo. O filme narra a história de uma família que foge da Alemanha nazista desembarcando no Brasil, por volta de 1937, onde compra um hotel que será mais tarde ponto de simpatizantes do nazismo. Em plena ditadura militar, Aleluia, Gretchen é como uma resposta ao silêncio que a censura tinha provocado no cinema nacional, a representação dos oficiais nazistas tinha endereço óbvio naqueles idos de intensa repressão militar.

Em 1980, encontramos o longa carioca $O$ Torturador, uma realização da Magnus Filme, com produção de Jece Valadão e direção de Antonio Calmon. O roteiro é assinado por Jece Valadão, Antonio Calmon e Alberto Magno. No elenco nomes como Vera Gimenez, Otávio Augusto, Anselmo Vasconcelos, Jorge Fernando entre outros. E conta com a participação especial de John Herbert e Moacir Deriquem. A história de $O$ Torturador desenrola-se em um país imaginário da América do Sul, cuja capital, chamada Corumbaí, é dominada pelo ditador presidente Georges, ex-capitão do exército. Nas suas atividades no passado, o ditador tinha sido um violento torturador a serviço de alguns grupos. Mas em uma trama paralela Jonas e seu fiel amigo são contratados por judeus sionistas para capturarem o nazista Herman Stahl, condenado em Nuremberg por crimes praticados durante a Segunda Guerra Mundial.

Dentre os curtas e médias-metragens de ficção, somente quatro foram produzidos em todo o período pesquisado. Blunn, o desafio de uma raça é uma produção de 1980, dirigido por Gilson Giehl em Florianópolis, Santa Catarina. O filme de 30 minutos conta a trajetória de uma família com origens judaicas numa comunidade nazista durante a Segunda Guerra Mundial. Sete anos depois, Regime de frustração resolve enfrentar os temas dos ex-combatentes de frente, como as neuroses de guerra. Esta película narra a história de Gregório, um ex-combatente da FEB alcoólatra, neurótico e frustrado que deixa a sua 
mulher e se refugia no campo, tendo apenas como companhia a jovem filha. O filme se passa em 1956, no Rio Grande do Sul, durante o governo Juscelino Kubitschek. Mas as vidas de pai e filha irão mudar com a chegada de Vicente, um homem rico que, a caminho de Porto Alegre, pede abrigo por uma noite. Este curta ficcional é uma produção da Nascer Filmes, com roteiro, montagem e direção de Márcia Lara.

Dez anos de silêncio, sem um filme ficcional que tratasse do tema, For All - Trampolim da Vitória (1997), de Luiz Carlos Lacerda e Bruza Ferraz é lançado no país. Sabe-se hoje que a participação do Brasil na Segunda Guerra Mundial teve conotações mais econômico-políticas do que ideológico-militares, uma vez que o próprio Getúlio Vargas em meados de 1940 declarara publicamente a sua simpatia ao nazi-fascismo, apesar de defender uma posição de neutralidade para o Brasil em relação às nações beligerantes. E foi com a entrada do capital norte-americano para financiar a construção da Usina Siderúrgica de Volta Redonda, reforçando o projeto nacionaldesenvolvimentista do Estado Novo, que Getúlio Vargas resolveu se unir aos Aliados e declarar guerra aos países do Eixo em 1942. Esta aliança resultou na concessão de uma parte da costa brasileira para que fosse construída uma base militar norte-americana. Este é o cenário de For All..., mais especificadamente a base Parnamirim Field em Natal (RN) de 1943, no nordeste brasileiro.

O enredo gira em torno de uma família de classe média que é abalada pela convivência com os soldados norte-americanos que trouxeram não apenas novidades em eletrodomésticos e dólares para a região, mas principalmente o glamour de Hollywood. São nas festas em estilos hollywoodianos, realizadas na base e liberadas "para todos", dentro de uma política de boa vizinhança, que o american way of life é oferecido aos brasileiros. Tanto que o namoro da filha da família Sandrini com o oficial estrangeiro é incentivado pela mãe, dentro de uma perspectiva de ascensão social. A comédia faz raras alusões à participação efetiva dos brasileiros na guerra que se desenrolava na Europa, longe do território brasileiro. Uma delas é a cena em que se pode ouvir notícias pelo rádio sobre a situação do Brasil no conflito mundial, fazendo referência aos aviões derrubados e navios torpedeados. Cabe ao espectador subentender a dimensão deste envolvimento efetivo dos brasileiros no front.

Em 1998 é lançado o curta-metragem Tangerine Girl, o filme narra a história de uma garota ingênua no nordeste brasileiro que se encanta por um dirigível que lhe atira presentes, até que um dia cai do céu um bilhete. É 1942, a cidade de Fortaleza $(\mathrm{CE})$ abriga bases norteamericanas, a garota irá se deparar com tudo o que a guerra tem de mais fascinante e trágico. Tangerine Girl é uma co-produção da LBBoubli Produções e BSB Cinema Produções, dirigida por Liloye Boubli. A história é baseada em um conto homônimo de Raquel de Queiroz. Este filme é a primeira investida da BSB Cinema Produções, produtora de Brasília dos irmãos Erik de Castro e Christian de Castro, em filmes que 
abordam a temática do "Brasil na Segunda Guerra". A produtora brasiliense será responsável mais tarde por três documentários de longa-metragem que compõem uma trilogia sobre a participação do Brasil na Segunda Guerra Mundial. São eles: Senta a Pua! (1999), A Cobra Fumou (2002) e O Brasil na Batalha do Atlântico (2012), dos quais tratarei mais adiante.

Outros filmes ficcionais de curta e longa-metragem foram lançados no país nos anos de 2000, estes fazem parte de um conjunto de filmes que sinalizam o interesse de uma nova geração de cineastas brasileiros sobre as histórias do Brasil na Segunda Guerra, produto de uma redescoberta do tema ocorrido nos anos de 1990.

\section{Brasil na Segunda Guerra, um tema redescoberto}

Só a partir de 1990 nota-se um crescente interesse dos cineastas pela memória da FEB, aspecto que vai ser intensificado na segunda metade dos anos 2000. Muitos dos filmes documentários deste período 1990/2000 assumem um compromisso com o passado dos ex-combatentes brasileiros, há uma "vontade de memória", os filmes são produzidos a partir de uma única premissa: é preciso combater o esquecimento. O testemunho oral é a porta de entrada para este passado negado desde 1945, um novo tipo de documentário começa a ganhar força nesta filmografia sobre a FEB, ao invés de colagens (ou edições) de trechos de filmes atualidades e registros cívicos predomina os testemunhos orais dos ex-combatentes que aceitam o desafio de rememorar os anos de guerra em frente a uma (ou mais) câmera de uma equipe de cinema. Para além das histórias orais, o veterano de guerra começa a ganhar uma cara no cinema brasileiro, uma maior visibilidade. Se anteriormente, nos cinejornais do DIP os combatentes figuraram como membros de um corpo uno, o Estado, ${ }^{19}$ mergulhados na imensidão das tropas, nos documentários dos anos 1990/2000 suas figuras são individualizadas, por mais que as lembranças que narram venham compor um conjunto de testemunhos que são ordenados para favorecer uma narrativa fílmica.

$\mathrm{Na}$ virada da década, as primeiras produções não focam a FEB ou o ex-combatente brasileiro, mas um tema correlato, as artes e as culturas no tempo de guerra e no pós-guerra. São documentários que exploram o período da Segunda Guerra sob o viés de um contexto político, artístico e cultural que marcou o século XX. Anos 30: Entre Duas Guerras, Entre Duas Artes é produto deste movimento, a parceria entre a Orion Cinema e Vídeo e o Instituto Itaú Cultural, iniciada em 1989, resulta em um curta-metragem de não-ficção que reúne pintura, arquitetura e trechos de outras películas, dando destaque para obras como as de Alfredo Volpi, Flávio de Carvalho, Candido Portinari, Di Cavalcanti, Lasar Segall, para traçar uma impressão do nacionalismo no período entre guerras. A direção e roteiro são de Décio Pignatari. A narração 
é feita por Esther Góes. No ano seguinte, realizam mais um projeto de um curta-metragem de não-ficção sobre o tema da guerra. No Tempo da Segunda Guerra (1990) é um filme produzido na cidade de São Paulo por André Klotzel, diretor mais tarde de Memórias Póstumas (2001). O documentário procura reconstituir a cultura brasileira durante o auge do Estado Novo e o período que transcorreu a Segunda Guerra Mundial. Em 1991, a Orion Cinema e Vídeo e o Instituto Itaú Cultural ainda produzem Novos rumos: o pós-guerra, um curta documental que trata das mudanças nas artes durante o período entre o fim da Segunda Guerra e o suicídio do presidente Getúlio Vargas. O roteiro é de Frederico Moraes, Maria Cristina Castilho Costa e Roberto Moreira, e a direção é de Mirella Martinelli.

Mas em 1991 é lançado um documentário de longa-metragem que marca o início de uma "batalha" pela memória da FEB no cinema brasileiro. Rádio Auriverde de Sylvio Back causa uma enorme polêmica, resultando inclusive em boicotes ao filme nas salas de exibição. Por onde exibiu o seu documentário, Back foi hostilizado por ex-combatentes da FEB, chamado de "porco", "canalha" e "nazista". No Jornal do Brasil de 12 de maio de 1992 o coronel Sérgio Gomes Pereira, presidente da Associação Nacional dos Veteranos da FEB na época, acusou o cineasta de adulteração e calúnia:

O filme é completamente inventado da cabeça dele. Ele adulterou fotos históricas que nós lhe emprestamos de boa fé. Em uma delas, onde aparecem os generais Eurico Gaspar Dutra e Mark Clark [...] ele tirou a farda dos militares da cintura para baixo e vestiu-lhes calções de futebol. ${ }^{20}$

Pela primeira vez um filme brasileiro lançava um olhar desmistificador para a memória heróica da FEB, apresentando os pracinhas como vítimas dos interesses econômicos e políticos do Estado Novo de Getúlio Vargas. O seu tom irônico não agradou aos veteranos da FEB, assim como aos críticos da época. Ainda hoje é difícil encontrar quem faça elogios a este filme, inclusive dentre os historiadores da FEB e da Segunda Guerra Mundial. Francisco Ferraz foi quem melhor localizou com destreza o lugar que Rádio Auriverde ocupa na construção da memória da FEB no pós-regime militar. O alvo do filme não é os ex-combatentes, mas as Forças Armadas enquanto instituição responsável por um Estado autoritário e repressor no Brasil dos anos de 1960/1980. O filme foi uma “[...] reação a uma memória laudatória e grandiloqüente, apropriada frequentemente pelos setores à direita da sociedade brasileira", analisou o historiador. ${ }^{21}$

A ironia presente em Rádio Auriverde não é gratuita, mas parte de uma estratégia discursiva comum aos documentários reflexivos. O cineasta convida o espectador a pensar juntamente com ele o quanto e como a memória e a história da FEB encontram-se revestidas de uma "aura" que insiste em eternizar 
mitos e herois. Por mais agudo que tenha sido o ataque à memória oficial da FEB, o documentário vale não pelo o que diz, mas como diz, como procurei demonstrar em outro trabalho. ${ }^{22}$

Se no início da década de 1990, o filme de Back surgiu como uma amostra de uma geração intencionada a desmistificar (ou demolir) a memória oficial da FEB, já no final dela uma nova geração de jovens realizadores começa a esboçar um cinema preocupado com um projeto de memória dos ex-combatentes brasileiros. A BSB Cinema Produções, produtora de Brasília dos irmãos Erik de Castro e Christian de Castro, em 1999 e 2002, realizam dois documentários de longa-metragem, respectivamente: Senta a Pua! e A Cobra Fumou. O primeiro teve a direção de Erik de Castro e narra as lembranças dos ex-combatentes da FAB (Força Aérea Brasileira). O filme é inspirado no livro homônimo do brigadeiro Rui Moreira Lima. Ao enfatizar no documentário as inúmeras missões de cada piloto, os feitos das batalhas, a tecnologia de guerra personificada nos aviões P-47 em um tom didático, Erick de Castro não escapou de ter seu filme condenado pela crítica como uma "homenagem ufanista" ou como um "institucional da Força Aérea Brasileira". Mas agradou a maioria por trazer pela primeira vez ao cinema brasileiro os testemunhos da guerra, os ex-pilotos narram seus medos, suas angústias para a câmera do diretor.

A Cobra Fumou já tem um tratamento diferente, o diretor Vinicius Reis aparece interagindo com os veteranos da FEB, o filme funciona como um diário do cineasta na busca por histórias dos brasileiros na Segunda Guerra. Vinicius Reis vai até a Itália para percorrer os lugares em que os febianos travaram as suas batalhas nos apeninos. Em A Cobra Fumou os oficiais têm voz, mas quem realmente ganha destaque é o pracinha humilde, despojado, homem do povo. Se para os oficiais da FEB o rememorar assume a conotação de um dever moral, para alguns pracinhas que estiveram na linha de frente as lembranças da guerra são incômodas, dolorosas, como podemos perceber no filme em meio a silêncios, sussurros ou lágrimas. A Cobra Fumou não se prende aos feitos heroicos dos ex-combatentes, procura um tom acima, valoriza os aspectos humanos daqueles que foram enviados para combater na Itália. ${ }^{23}$

Um Brasileiro no Dia D, documentário produzido e dirigido pelo músico João Barone, baterista do grupo Paralamas do Sucesso, repete a fórmula de A Cobra Fumou, pelo menos ao oferecer ao espectador "um autêntico roadmovie" como descrito na sua sinopse. Filho de ex-combatente, Barone produziu e dirigiu o filme que foi lançado primeiramente em DVD e vendido em bancas de jornais e revistas no país, e, posteriormente, exibido em canais de TV por assinatura, como History Channel. O documentário não percorreu as salas de cinema do Brasil.

Com o seu jipe de guerra restaurado, Barone embarca para a França com o objetivo de visitar os cenários históricos da Normandia, onde ocorreu um dos principais episódios da Segunda Guerra Mundial. O fio condutor é 
a história de Pierre Closterman, nascido em Curitiba em 1921, filho de mãe brasileira e pai francês. Closterman foi lutar ao lado dos Aliados na Inglaterra a pedido do pai, na época diplomata francês. Como aviador, combateu pela Força Aérea Inglesa, sendo o único brasileiro a atuar no Dia D. O filme de Barone foi produzido pela ocasião das homenagens aos 60 anos do Dia D em 06 de junho de 2004, quando ele e sua equipe estiveram na França.

Em 2007 é produzido O Lapa Azul (2007), um filme documentário de longa-metragem realizado pelo major Durval Lourenço Pereira Junior que retrata as histórias de ex-combatentes da FEB de Juiz de Fora (MG) que integraram o III Batalhão do $11^{\circ}$ Regimento de Infantaria, conhecido como "Lapa Azul". Para uma nova geração de oficiais do pós-ditadura os ressentimentos de 1964 ainda são atuais e definem as representações dos militares no cinema, inclusive as da FEB. Durval Junior faz o filme na intenção de contra-atacar este tipo de representação que se acredita predominante na mídia brasileira. Em O Lapa $A z u l$ o diretor não deixa de exaltar a FEB, seus feitos heróicos, as histórias de resistência e tenacidade dos pracinhas, mas os testemunhos dos ex-combatentes parecem agregar ao filme uma dimensão mais humana. $O$ jeito simples do mineiro falar traz outro tom à narrativa da memória da FEB, o espectador se pega em alguns momentos encantado não apenas pelo o que dizem mas pela forma com que certos veteranos narram suas lembranças de guerra. ${ }^{24}$

Senta a Pua!, A Cobra Fumou, Um Brasileiro no Dia D e O Lapa $A z u l$ são exemplos de um tipo de cinema que nos anos de 2000 passou a ser predominante na representação da FEB. O “documentário de memória” baseado em narrativas testemunhais evoca os personagens sociais como protagonistas de suas histórias de vida, assim os cineastas de uma nova geração saíram em busca destas histórias repletas de experiências e valores humanos. A partir de 2008, alguns documentários que retrataram a participação do Brasil no conflito mundial foram produzidos e lançados no país. Nos últimos oito anos 06 documentários abordaram o tema, priorizando os registros dos testemunhos dos ex-combatentes ou de brasileiros que testemunharam episódios importantes desta época. É o caso de $U-507$, documentário de curta-metragem dirigido e roteirizado por Rubens Carvalho, lançado em agosto de 2008. O filme aborda o tema do afundamento de quatro navios brasileiros na costa de Sergipe durante a guerra. São entrevistados moradores de Mosqueiro e Areia Branca, em Aracaju, testemunhas do clima de guerra decorrente daqueles torpedeamentos na região. O submarino U-507 naufragou em 13 de janeiro de 1943 nas proximidades de Natal (RN), após ser atacado por um Avião Catalina norte-americano do Esquadrão VP-83. Na ocasião, morreram 54 tripulantes do U-boat.

Em 2009 as experiências de descendentes de alemães no Sul do Brasil sobre a perseguição ocorrida durante a Segunda Guerra, a partir da Campanha de Nacionalização do presidente Getúlio Vargas e a entrada do Brasil na Guerra em 1942, ganha destaque pela primeira vez por meio do documentário Sem 
Palavras (2009). Dirigido pela cineasta catarinenese Kátia Klock, o filme visa as memórias de quem era criança nos anos de 1940. Com os idiomas alemão, italiano e japonês proibidos no território nacional, a vida no Brasil se tornou difícil para os estrangeiros e seus descendentes que foram obrigados a se silenciarem, a abandonarem a sua cultura, a sua língua materna. Foram entrevistados moradores de Blumenau, Vila Itoupava, Pomerode, Balneário Camboriú, Joinville, Jaraguá do Sul, Brusque, Jaraguá do Sul e Florianópolis. Além dos depoimentos, a diretora recorreu a cenas dramatizadas para recriar o clima da época com a participação de não atores, descendentes de famílias alemãs de Blumenau, bem ao estilo do docudrama. ${ }^{25}$ Sem Palavras teve a consultoria histórica de Janine Gomes da Silva que defendeu em 2004 sua tese de Doutorado em História sobre o tema do filme, intitulada "Tempo de Lembrar, Tempo de Esquecer", pela Universidade Federal de Santa Catarina (UFSC).

Ainda sobre as ações dos submarinos alemães na costa brasileira, temos o lançamento em 2012 de O Brasil na Batalha do Atlântico, documentário de longa-metragem de Erik de Castro, pela BSB Cinema. Com este documentário, a BSB Cinema completa a sua trilogia sobre a memória da participação do Brasil na Segunda Guerra Mundial, tendo produzido Senta a Pua! (1999) e A Cobra Fumou (2002). Os personagens de O Brasil na Batalha do Atlântico são os veteranos das Marinhas Mercante e de Guerra, e os sobreviventes dos naufrágios. Em 16 de março de 2012, há registros da exibição de $O$ Peso da Guerra no programa "Primeira Exibição" da Cinemateca Brasileira, em São Paulo. O filme documental de média-metragem, dirigido por Alexandre Naval Almeida, teve a Associação dos Ex-combatentes da FEB, seção de São Paulo, como locação e contou com a participação dos ex-combatentes.

Abrasivo (2013), um filme de Lucas Gervilla, é outro documentário que explora as lembranças dos veteranos da FEB, mas desta vez o foco não é a guerra, mas a vida que estes homens tinham no Brasil antes de serem convocados para participaram do conflito na Europa. O curta de 19 minutos traz depoimentos de veteranos da FEB dos Estados de São Paulo, Rio Grande do Sul, Rio de Janeiro e Mato Grosso do Sul. João Barone faz a sua segunda investida no tema, em $O$ Caminho dos Heróis ele viaja por 15 cidades italianas refazendo o mesmo caminho dos ex-combatentes. O documentário foi exibido no History em julho de 2014. ${ }^{26}$

Pela internet foi possível identificar que há outros documentários sobre o tema em fase de produção. Destaque para Soldados da Borracha: a Brigada Esquecida, dirigido por Eva Neide, que retrata uma história pouco contada desta participação brasileira na Segunda Guerra. O documentário visa tirar do esquecimento os brasileiros que foram recrutados e enviados para a selva Amazônica para extrair látex atendendo ao esforço de guerra do Brasil naqueles anos de 1940. Até hoje estes homens lutam contra a denegação, querem o direito de ser reconhecidos como ex-combatentes. Já Que falta que me fez 
é uma iniciativa independente de Daniel Mata Roque da Pátria Filmes, com gravações feitas com ex-combatentes no Rio de Janeiro e Juiz de Fora (MG). Ambos os filmes não foram contabilizados no mapeamento desta pesquisa por ainda não terem sido lançados no país.

No campo do cinema ficcional, o tema do "Brasil na Segunda Guerra" não parece ganhar a mesma atenção dada pelo documentário nos anos de 2000. Uma década depois do lançamento de Senta a Pua!, um único filme de ficção sobre o tema é produzido no país. Torpedo (2009), curta de 15 minutos, sob a direção de Márcio Câmara, de Fortaleza (CE), retrata os episódios que se sucederam 15 minutos antes do impacto do torpedo que atingiu o navio Baipendi na costa brasileira em 15 de agosto de 1942.

Em 2012 é lançado no Brasil o longa ficcional Corações Sujos, de Vicente Amorim. O filme tem seus méritos por tratar de um tema da Segunda Guerra pouco conhecido pelos brasileiros. Uma transposição do livro homônimo de Fernando Morais para o cinema, conta a história trágica de imigrantes japoneses no Brasil do fim da guerra. Quando o Japão foi derrotado, muitos destes imigrantes não aceitaram a rendição do Imperador, como súditos fiéis (mesmo em um país distante) passaram a defender a honra do seu povo. Reunidos em organizações passaram a reprimir e assassinar os "derrotistas".

Se mesmo nestes últimos 15 anos o número de filmes ficcionais lançados no país sobre o tema ainda é tímido, temos que pela primeira vez um episódio da participação do Brasil na Segunda Guerra ganha as telas de cinema com $A$ Estrada 47 (2013), coprodução Brasil, Itália e Portugal, dirigida por Vicente Ferraz. No melhor estilo dos "filmes de guerra", A Estrada 47 narra a história de quatro soldados brasileiros da FEB, que depois de sofrerem um ataque de pânico coletivo no sopé do Monte Castelo, descem a montanha abandonando os seus postos. Sabendo que se retornassem ao Batalhão teriam que enfrentar a corte marcial, decidem por desativar as minas terrestres na estrada 47 como forma de se redimirem dos erros cometidos. Apesar do rótulo "filme de guerra", $A$ Estrada 47 tem o mérito de não colocar em primeiro plano os horrores da guerra, mas sim os dramas e conflitos dos personagens diante daquele contexto. Entretanto, este tratamento mais humano, em que expõe a fragilidade do homem diante da guerra, aspecto que foi comum a brasileiros, alemães, italianos, ingleses, norte-americanos etc, não agradou a todos. Em um site de crítica cinematográfica o internauta que se apresenta como "Marcelo A." faz o seguinte comentário a respeito de $A$ Estrada 47 e o seu diretor:

Filme medíocre, dirigido por Vicente Ferraz, um diretor medíocre, que teve sua formação em Cuba e tudo que produziu tem fortes vínculos ideológicos com o comunismo, usou todas as técnicas possíveis para diminuir a ação militar da FEB na $2^{\text {a }}$ Guerra Mundial, retratando os bravos e heroicos pracinhas como meros covardes e combatentes 
incompetentes, o que sabemos que não condiz com a verdade histórica. O filme é praticamente cochichado pelo Soldado Guimarães que em todo o tempo culpa seu pai por estar ali e se questiona o porquê da FEB estar combatendo na $2^{\text {a }}$ Guerra, como se essa obrigação fosse de todos, menos dos brasileiros [...] não assista a esse filme tendencioso, converse com Pracinhas que estiveram lá, deixe que eles contem a verdade de suas ações, vão te contar seus medos, suas dificuldades, seus ideais e sua certezas do porque estavam combatendo, vão contar como foram heróis e onde encontraram coragem para superar cada obstáculo. A história contada por eles é outra, não há nada de covardia e "eles estiveram lá". Honrem seus heróis porque eles são o seu legado. ${ }^{27}$

Mais uma vez a ponte entre o sentimento de anticomunismo e a representação da FEB aparece no julgamento de um filme brasileiro contemporâneo que arrisca olhar para os brasileiros que lutaram na Itália com uma perspectiva diferenciada daquela apresentada pela memória heroica que querem cristalizar. Ao final do filme os pracinhas surgem cansados, abatidos, de longe parecem heróis. Apesar de satisfeitos pela missão cumprida não esboçam qualquer feição de ânimo enquanto as tropas Aliadas avançam pelas ruas da cidade italiana libertada. Se existe algum sentimento de heroismo nos personagens, não é pela guerra em si, mas sim pelo orgulho de ter contribuído pela paz e liberdade daquele povo italiano sofrido, como sintetiza o Soldado Guimarães, em suas narrativas ao pai que o enviara para a guerra.

\section{Considerações finais}

Nas proximidades dos 70 anos do desembarque dos soldados brasileiros em Nápoles, se vê um novo cenário se desenhando para a memória da FEB e dos ex-combatentes no cinema brasileiro, e o documentário é o grande responsável. Interessante é notar a força do longa documental neste período dando maior visibilidade a esta memória. Por outro lado, é no mínimo curioso acompanhar na cinematografia brasileira o quanto o cinema de não-ficção (englobando aqui cinejornais ou filmes atualidades, e documentários) se interessou mais pela temática da Segunda Guerra Mundial e pela participação dos brasileiros neste combate do que o cinema de ficção. O lugar da memória da FEB e do Brasil na Segunda Guerra no cinema brasileiro é indiscutivelmente a não-ficção. De 1940 a 2015 foram produzidos 246 filmes de não-ficção no país que trataram do tema - 94,61\% de todos os filmes catalogados -, a maioria são cinejornais $(93,49 \%)$ que reflete uma produção de filmes que atravessa mais de 40 anos da história do país e da sua cinematografia, deixando de ser produzido em 
meados de 1980 quando a televisão conquista definitivamente o seu espaço nos lares dos brasileiros.

Temos que ressaltar que somente a partir de 1930 é que o documentário começa a ganhar uma identidade, em termos estéticos e de linguagem cinematográfica, na história do cinema mundial diferenciando-se dos filmes naturais e dos filmes atualidades da época. Porém, poucos filmes documentários sobre o "Brasil na Segunda Guerra" foram produzidos nas décadas de 1940 a 1970 no país. Uma explicação plausível para a representação da FEB e do Brasil na guerra ter ficado circunscrita aos cinejornais pode estar no fato de que quando o documentário brasileiro começou a assumir um caráter mais autoral nas décadas de 1960/70, libertando-se do peso da produção de viés institucional e de propaganda herdada do Estado Novo, os documentaristas se interessaram por temas e tratamentos mais sociológicos a respeito da realidade brasileira. Havia uma necessidade dos jovens realizadores em revelar em seus filmes o Brasil aos brasileiros, uma preocupação mais com o presente do que com o passado.

Em mais de meio século o interesse do cinema brasileiro pela representação da FEB e do Brasil na Segunda Guerra Mundial foi ínfimo. Com exceção do período em que o Brasil esteve em guerra (1940-1945), foram esporádicas as produções ao longo das décadas no pós-guerra. Somente na segunda metade dos anos de 1960 um número maior de filmes é produzido em plena ditadura civil-militar, fato que pode estar associado à aproximação da memória da FEB ao regime. Por outro lado, foi nos anos de 1990/2000 que surge uma produção mais contínua e mais plural sobre a temática, o que nos autoriza a dizer que o cinema brasileiro redescobriu a FEB e o Brasil na Segunda Guerra.

Mas o que explica este desinteresse do cinema brasileiro pelo passado do Brasil na Segunda Guerra ao longo de 70 anos? Sem procurar dar respostas definitivas, é possível pensarmos em duas hipóteses: a) a sensação de irrealidade da guerra por parte do povo brasileiro; e b) o desinteresse da historiografia brasileira, principalmente a partir de 1960, com a história militar e em especial com a história da FEB na Itália.

O governo Getúlio Vargas, desde a entrada do Brasil no conflito bélico, procurou por meio de uma política de escassez relativa do pão e da gasolina criar no país um front interno, tentando aproximar a experiência da guerra do cotidiano dos brasileiros. Mas o povo não atendeu aos apelos destas práticas de mobilização, o pão de guerra e a restrição ao uso do automóvel — na época, um dos objetos mais desejados do homem urbano, um emblema do próprio progresso e da modernidade - soaram como medidas inaceitáveis, como intervenções descabidas do governo em hábitos já enraizados. A verdade é que a escassez do pão, sempre relativa, nunca representou aos brasileiros um limite incontornável, a classe média jamais experimentou a fome como uma 
conseqüência da guerra na Europa. Pelo contrário, não passou de momentos divertidos nas filas, em que sempre se encontrava algum jeitinho para burlar as restrições à venda do pão. Logo tratavam de arranjar aquele padeiro "amigo" que providenciava o pão por fora. Fatores como este, de recusa à mobilização do Estado Novo a um front interno, associados a outros como a dos nossos soldados que participaram de combates reais, mas distantes do país, foram as matrizes de uma certa sensação de irrealidade da guerra, segundo Roney Cytrynowicz ${ }^{28}$. Ou seja, o povo brasileiro não experimentou “em si” o que é uma guerra em seu próprio território, não passou fome, não presenciou seus lares em chamas depois de clarões, não teve medo da morte. E mais, raras foram as exceções de brasileiros da classe média que tenham se alistado voluntariamente como soldados engajados na luta contra os "impiedosos totalitários", como a propaganda ideológica da época descrevia o inimigo "adotado".

Toda esta sensação contraditória de um país em "guerra sem guerra" pode ser uma das explicações do cinema nacional ter se preocupado pouco com a temática da Segunda Guerra. Se durante o conflito esta sensação reinou no Brasil, o que dizer dos anos do pós-guerra, com uma FEB desmobilizada, tendo a sua experiência militar jogada na lata de lixo da história, e com os excombatentes ridicularizados pelos rumores do "turismo de guerra". Restaram a alguns brasileiros acreditar em uma imagem heroica e grandiloqüente da FEB, ingredientes de uma memória oficial mantida e difundida até hoje pelo Exército.

É verdade que em uma perspectiva panorâmica da produção de 1940 a 2015 nota-se que a maioria dos filmes, inclusive os produzidos de forma independente, reforça os mitos da FEB, as conquistas de Monte Castelo e de Montese, traçando imagens de uma FEB vitoriosa. ${ }^{29} \mathrm{Com}$ raras exceções há uma crítica a esta memória heroica, pelo contrário, há uma preocupação dos documentaristas em registrar as memórias dos ex-combatentes mais como uma resposta ao esquecimento.

Era difícil para o conjunto dos realizadores do cinema brasileiro não ter o Exército como referência quando o assunto era a Segunda Guerra e a FEB. Devemos lembrar que a FEB era (e ainda é) a reserva simbólica do Exército. Então, quem mais poderia dar suporte aos roteiros de filmes que tinham como enredo "a epopéia dos expedicionários brasileiros"? Durante todos estes anos, foram os historiadores militares de carreira e os próprios ex-combatentes que trataram de contar a história da atuação do Brasil neste conflito bélico de proporções internacionais. Suas pesquisas, diários e memórias encontraram respaldo na Biblioteca do Exército. Enquanto isto, as universidades brasileiras já em meados de 1960 experimentaram um cenário de poucas "boas vindas" com o regime militar. Situação que afastou dos estudos da história militar historiadores que tivessem alguma proximidade com os ideais da política de esquerda. Como a FEB começava a se identificar com as Forças Armadas, com o militarismo repressor dos generais, era comum que o seu passado sofresse o 
desprezo de toda uma geração de historiadores, jornalistas e cineastas.

Os filmes produzidos nos anos de 2000 integram tardiamente no Brasil uma política de memória sobre o passado da Segunda Guerra Mundial, por outro lado, têm mostrado preocupação por retratar episódios da guerra pouco explorados, como os afundamentos dos navios brasileiros por submarinos alemães e a "Batalha da Borracha". Outros tantos temas se encontram silenciados ou pouco explorados como o da participação feminina na guerra. Para o cinema brasileiro do pós-guerra a mulher sequer teve um papel de coadjuvante nesta guerra, quando na verdade sabemos que quando os homens são convocados para pegarem em armas são elas que assumem o protagonismo do esforço de guerra interno seja nos lares, indústrias e etc.

\section{NOTAS}

1 Para mais detalhes ver TOMAIM, Cássio dos Santos. Documentário e o Brasil na Segunda Guerra Mundial: antimilitarismo e anticomunismo como matrizes sensíveis. São Paulo: Intermeios; FAPESP, 2014.

2 Segundo Jean-Claude Bernadet, os primeiros trabalhos historiográficos na tentativa de abarcar o todo do cinema brasileiro consagrou uma visão ideológica que perdurou por muito tempo, a de que a nossa cinematografia sobrevivia de ciclos regionais esporádicos, era um eterno recomeçar. Sua leitura crítica desta historiografia atesta que o aspecto globalizante do panorama escondeu um recorte. A história do cinema brasileiro é a história do cinema de ficção de longa-metragem, deixando à margem toda uma enorme produção de filmes ficcionais e não-ficcionais, de curta e média-metragem, assim como os documentários de longa-metragem que, com uma exceção ou outra, foram apagados da história. Porém, o autor reconheceu que a noção de panorama foi útil em certa medida para o cinema brasileiro, uma vez que diante de um total desconhecimento os primeiros trabalhos foram responsáveis por reunir um corpus consistente da filmografia produzida no país, o que nos permitiu dizer que existíamos cinematograficamente tanto para o olhar estrangeiro quanto para nós mesmos. Mesmo contrariando o autor, este estudo segue uma perspectiva panorâmica do nosso cinema por acreditar que ainda se faz necessária tendo em vista a escassez de estudos sobre estes filmes produzidos no país a respeito do tema "Brasil na Segunda Guerra". Ver BERNARDET, Jean-Claude. Historiografia clássica do cinema brasileiro: metodologia e pedagogia. São Paulo: Annablume, 2004.

3 Para esta pesquisa foram consultados SILVA NETO, Antônio Leão. Dicionário de filmes brasileiros: longa metragem. São Bernardo do Campo, SP: Ed. do Autor, 2009; SILVA NETO, Antônio Leão. Dicionário de filmes brasileiros: curta e média metragem (1897 a 2005). São Bernardo do Campo, SP: Ed. do Autor, 2011.

4 CORSI, Francisco Luiz. Estado Novo: política externa e projeto nacional. São Paulo: Unesp, 2000.

5 MOURA, Gerson. Sucessos e ilusões: relações internacionais do Brasil durante e após a segunda guerra mundial. Rio de Janeiro: FGV, 1991.

6 Foram contabilizados aqui os filmes produzidos pelo DNI (Departamento Nacional de Informação), órgão que veio suceder o DIP depois de sua extinção em 25 de maio de 1945, ainda durante o Estado Novo. Este Departamento deu continuidade às atividades do antigo órgão, inclusive a produção do Cine Jornal Brasileiro que só foi cessada em 1946.

7 Para mais detalhes ver TOMAIM, Cássio dos Santos. "Janela da alma": cinejornal e Estado Novo - fragmentos de um discurso totalitário. São Paulo: Annablume; FAPESP, 2006. 
8 No pós-guerra a Atlântida ainda produziu outros 23 filmes sobre o assunto até 1949.

9 Para mais detalhes ver FERRAZ, Francisco César Alves. A guerra que não acabou: a reintegração social dos veteranos da força expedicionária brasileira (1945-2000). Tese (Doutorado). Faculdade de Filosofia, Letras e Ciências Humanas - FFLCH, Universidade de São Paulo, São Paulo, 2002.

10 De 1946 a 1949 a Associação de Ex-combatente do Brasil (AECB), nas suas mais diversas seções espalhadas pelo país, apresentava uma postura mais ativa tanto no que diz respeito à luta pelos direitos dos veteranos de guerra quanto aos mais variados temas políticos da vida nacional. Entretanto, a partir de 1950 a AECB assume uma postura mais conservadora, preferindo uma política conciliadora e colaboradora com as autoridades. O exemplo maior disto foi o silenciamento da associação diante das prisões, torturas e mortes de ex-combatentes durante a ditadura civil-militar, acusados de serem subversivos. Ver FERRAZ, Francisco César Alves. A guerra que não acabou: a reintegração social dos veteranos da força expedicionária brasileira (1945-2000). Tese (Doutorado). Faculdade de Filosofia, Letras e Ciências Humanas - FFLCH, Universidade de São Paulo, São Paulo, 2002.

11 Trecho extraído de comentário disponível na ficha do filme localizado no banco de dados da Cinemateca Brasileira.

12 Jurandyr Passos Noronha fundou em 1952, juntamente com Alberto Cavalcanti, a produtora Kino Filmes, em São Paulo.

13 Para mais detalhes ver SIMIS, Anita. Estado e cinema no Brasil. São Paulo: Annablume; FAPESP, 1996.

14 Breves referências a este filme Uma parada de Antonio Manoel podem ser encontradas em ARAUJO, Virginia Gil. "Censurado - Uma Parada" (1977) - Um estudo sobre a atuação de Antonio Manuel durante da última ditadura militar no Brasil. Revista Afuera, n.15, dez. 2015. Disponível em http://www.revistaafuera.com/articulo.php?id=357\&nro=15. Acessado em 11 mar. 2016.

15 Trecho extraído de comentário disponível na ficha do filme localizado no banco de dados da Cinemateca Brasileira.

16 O levante comunista de 1935 é lido pelos militares como um episódio de traição dos militares revolucionários que pegaram em armas e assassinaram alguns companheiros de farda enquanto dormiam. Desde 1936 entrou para o calendário cívico das Forças Armadas, sendo relembrado anualmente nos quartéis.

17 Como procurei demonstrar em trabalho anterior, “o 'Novembro de 1935' nas mãos dos militares foi transformado em um 'reduto' simbólico de onde se poderia fazer uso do comunismo como uma herança maldita para a orquestração da Doutrina de Segurança Nacional.” Por sua vez, os militares também buscavam na memória heroica da FEB elementos de apoio ao regime, como lugar de memória a "Campanha da Itália" era aproximada dos valores da "revolução de 1964". O ponto alto da instrumentalização dos ressentimentos durante as homenagens aos mortos da Intentona Comunista de 1935 em relação à memória oficial da FEB pode ser encontrado na Ordem do Dia do Exército de 1980, proferida pelo então ministro Interino do Exército general Ernani Ayrosa da Silva, febiano e um dos idealizadores da Operação Bandeirantes (Oban) um dos principais dispositivos de repressão da ditadura. Na declaração o "Novembro de 1935" aparece como um evento que serviu de lição e de advertência aos brasileiros, revelando “[...] a verdadeira face do comunismo". Então, rememorar 1935 era renovar o juramento do Exército de fidelidade à democracia, no mesmo sentido que as "[...] pelejas pela Independência onde se forjou, no desagravo à honra nacional nas lutas continentais, na campanha pela abolição 
da escravatura, na participação decisiva na proclamação da República e no combate ao nazifascismo nos campos gelados da Itália". Assim recordava o saudoso ex-combatente das glórias da FEB em meio a um discurso marcado pelo anticomunismo. ver TOMAIM, Cássio dos Santos. Documentário e o Brasil na Segunda Guerra Mundial: antimilitarismo e anticomunismo como matrizes sensíveis. São Paulo: Intermeios; FAPESP, 2014, p.234-236.

18 Uma breve referência ao filme Os carrascos estão entre nós pode ser encontrada no seguinte endereço eletrônico http://chiadosecanudos.blogspot.com.br/2012/09/os-carrascos-estao-entrenos-1968.html. Acessado em 11 mar. 2016.

19 Para mais detalhes ver TOMAIM, Cássio dos Santos. "Janela da alma”: cinejornal e Estado Novo - fragmentos de um discurso totalitário. São Paulo: Annablume; FAPESP, 2006.

20 TINOCO, Pedro. Ex-pracinhas combatem Sylvio Back. Jornal do Brasil, Caderno B, 12 maio 1992, p.6.

21 FERRAZ, Francisco César Alves. A guerra que não acabou: a reintegração social dos veteranos da força expedicionária brasileira (1945-2000). Tese (Doutorado). Faculdade de Filosofia, Letras e Ciências Humanas - FFLCH, Universidade de São Paulo, São Paulo, 2002, p.343.

22 Para mais detalhes ver TOMAIM, Cássio dos Santos. Documentário e o Brasil na Segunda Guerra Mundial: antimilitarismo e anticomunismo como matrizes sensíveis. São Paulo: Intermeios; FAPESP, 2014.

23 Ibidem, Idem.

24 Ibidem, Idem.

25 Fundação Catarinense de Cultura (FCC), Sem Palavras. Disponível em http://www.fcc. sc.gov.br/index.php?mod=pagina\&id=7233. Acessado em 29 fev. 2016.

26 Documentário de João Barone sobre participação brasileira na Segunda Guerra estreia nesta quinta-feira. Disponível em <http://dc.clicrbs.com.br/sc/entretenimento/noticia/2014/07/ documentario-de-joao-barone-sobre-participacao-brasileira-na-segunda-guerra-estreia-nestaquinta-feira-4564263.html>. Acessado em 20 fev. 2016.

27 Crítica de A Estrada 47. Disponível em <http://www.adorocinema.com/ usuarios-B20151004204925380758931/movie/202584/>. Acessado em 21 fev. 2016.

28 CYTRYNOWICZ, Roney. Guerra sem guerra: a mobilização e o cotidiano de São Paulo durante a Segunda Guerra Mundial. São Paulo: Edusp, Geração Editorial, 2000.

29 Devo ressaltar que esta interpretação se dá a partir das leituras das sinopses da maioria dos filmes e de alguns outros filmes assistidos.

Artigo recebido em março de 2016. Aceito em junho de 2016. 